Strafun S., Lysak A., Strafun O. Orthopaedic reconstruction in late period of brachial plexus injuries. Issue Rehabil. Orthop. Neurophysiol. Sport Promot. 2016; 17: 61-70.

\section{ORTHOPAEDIC RECONSTRUCTION IN LATE PERIOD OF BRACHIAL PLEXUS INJURIES}

Sergiy Strafun

Andrew Lysak

Oleksandr Strafun

State Institution "Institute of Traumatology and Orthopaedics of the Academy of Medical Sciences of Ukraine", Kyiv, Ukraine

\section{SUMMARY}

\section{Introduction}

Brachial plexus injury and peripheral nerve trauma at the level of neck and shoulder, are characterized as the result by a rough dysfunction of upper extremity, and in most cases lead to disability.

\section{Aim}

Description of possibilities of the orthopaedic reconstruction in the late period after upper brachial plexus injury.

\section{Patients, methods and results}

According to algorithms developed by J.Y. Alnot treatment tactics should be as follow. If within 21 days there are no signs of positive dynamics of restoration, patient must undergo examination. In case of visualisation of brachial plexus damage, or non-chronological recovery, surgery should be undertaken. In late period, or in case of function deficit, late orthopaedic reconstruction should be performed. Based on our classification, we developed the orthopaedic treatment tactics of brachial plexus lesions which affected the shoulder joint, depending on the severity of injury. Another way for the restoration of motion in the shoulder joint may be the approach depending on the level of brachial plexus lesion and preservation of muscles groups function in the shoulder girdle.
REKONSTRUKCJA ORTOPEDYCZNA W PÓŹNYM OKRESIE PO USZKODZENIU SPLOTU RAMIENNEGO

Sergiy Strafun

Andrew Lysak

Oleksandr Strafun

Institute of Traumatology and Orthopaedics of the Medical Sciences Academy of Ukraine, Ukraina

\section{STRESZCZENIE Wstęp}

Uraz splotu ramiennego, urazy nerwów obwodowych na poziomie szyi i barku, które wywołują znaczące dysfunkcje kończyny górnej, w większości przypadków prowadzą do niepełnosprawności.

\section{Cel}

Celem pracy był opis możliwości rekonstrukcji ortopedycznych w okresie późnym po uszkodzeniu górnej części splotu ramiennego.

\section{Pacjenci, metody i wyniki}

Zgodnie $\mathrm{z}$ algorytmami przedstawionymi przez J. Y. Alnot, taktyka leczenia powinna być następująca, jeżeli w ciągu 21 dni nie ma objawów dynamicznej, pozytywnej regeneracji, chorego należy poddać szczegółowemu badaniu. W przypadku zobrazowania uszkodzenia splotu ramiennego lub regeneracji w kolejności niechronologicznej, powinno być podjęte leczenie operacyjne. W okresie późnym, lub w przypadku wystąpienia deficytów funkcjonalnych, powinno się przeprowadzić wtórna rekonstrukcję ortopedyczną. W oparciu o naszą własną klasyfikację uszkodzeń, zaproponowaliśmy taktykę leczenia ortopedycznego uszkodzeń splotu ramiennego pozwalającą odtworzenie funkcji stawu ramiennego, w zależności od stopnia uszkodzenia. Innym sposobem odtworzenia ruchu w stawie 


\section{Conclusions}

Despite the development of brachial plexus neurotization techniques, orthopedic reconstructive surgeries occupy a stable niche in the treatment (including primary) of the patients and remain the only method of choice in case of the inefficient muscles reinervation.

Keywords: brachial plexus, reconstruction surgery, treatment's tactics

Date received: 19th September 2016

Date accepted: 17th October 2016

\section{Introduction}

Brachial plexus injury (ICD-10: S14.3) is a peripheral nerve trauma at the level of neck and shoulder, which is characterized by a rough dysfunction of upper extremity. According to Milesi, classification of the brachial plexus lesion is divided into: preganglionic (root avulsion) and postganglionic, which is subdivided into trunk injury (supraclavicular) and cord injury (subclavian). Depending on anatomical classification, brachial plexus injury is divided on the upper type of lesion (roots C5-C6 $\pm \mathrm{C} 7$, which leads to the dysfunction of the shoulder and elbow), lower type (C8-T1 \pm C7, dysfunction of the wrist) and total lesion (C5$\mathrm{T} 1$, and rough dysfunction of whole upper extremity) (Blaauw et al. 2008; South Glasgow University Hospitals Division 2010; Chung et al. 2012; Sakellariou et al. 2014).

According to the literature, it consists of $1.2 \%$ all polytrauma, and in 2012 it increased by $30 \%$ compared to 2009 . In $41 \%$ of cases, it is the upper type of lesion, that innervate the major muscle groups of the shoulder joint (deltoid muscle, rotator cuff, scapular group, and axillary-humeral group) (Midha R. 1997; Jain et al. 2012). According to A. Berger (1997), about 25-30\% (Цимбалюк ramiennym może być leczenie zależne od poziomu uszkodzenia oraz zachowanych funkcji grup mięśniowych obręczy barkowej.

\section{Wnioski}

Pomimo rozwoju technik neurotyzacji splotu ramiennego, zabiegi ortopedyczne rekonstrukcji u chorych stanowią tradycyjny sposób leczenia (łącznie z pierwotnie stosowanym) i pozostaje jedyną metodą z wyboru w przypadku braku reinerwacji mięśni.

Słowa kluczowe: splot ramienny, rekonstrukcja operacyjna, taktyki leczenia

Data otrzymania: 19 września 2016

Data zaakceptowania: 17 października 2016

та спів.авт. 2001), and reports of Scottish National Brachial Plexus Injury Service (2009-2010) about $12 \%$ of patients (including $7 \%$ after neurotization, and $5 \%$ as primary treatment) require the orthopedic correction (South Glasgow University Hospitals Division 2010).

\section{Aim}

Describe the possibilities of orthopaedic reconstruction in late period after the upper type brachial plexus injuries.

\section{Patients, methods and results}

According to algorithms developed by J.Y. Alnot, in case of upper (C5-C6 \pm C7) and total (C5-T1) lesions of the brachial plexus treatment tactics should be as follows:

In case of upper type of brachial plexus injury, if within 21 days there are no signs of positive dynamics in restoration of sensation or movements in the muscles of the shoulder girdle, the patient must have performed the ENMG examination, CT myelography and MRI of brachial plexus for the visualization of lesion and the early surgical intervention. If in 21 days after the injury we determine the coherent, 
positive restoration dynamics (in the proximal-distal direction), a course of conservative treatment should be prescribed, under the constant medical supervision. In case of future function deficits - late orthopedic reconstruction should be undertaken. In cases when 21 days after the injury appears discoherent dynamics (recovery takes place in appropriate terms, however reinnervation of certain muscles do not happen due to which there is some function loss of upper extremity), ENMG, CT myelography and MRI of the brachial plexus should be performed, and in case of visualization of injured locus, surgery on the nerves is performed. In the case when the lesion area is not identified and the dissociation of recovery pattern progresses (violation of correlation between recovery of sensation and of contractile function of muscles), treatment prolongation tactic is possible with orthopedic reconstructive surgeries at the end of possible time of self-recovery.

In the case of total brachial plexus lesion, if within 21 days from the date of injury there is no sign of recovery, ENMG examination, CT myelography and MRI of brachial plexus should be performed, and after localization of lesions, the early surgical intervention is suggested. In case of presence of the dynamic recovery that takes place in chronological order (from proximal to distal segments), a course of conservative therapy should be prescribed, with the late orthopedic treatment if it needed. If non-chronological recovery is observed (signs of recovery of the distal segment before proximal), CT myelography and MRI of brachial plexus are performed, and then, in the later period, after restoration of function of distal segments, the reconstructive orthopedic surgeries are performed to restore the function of the proximal part of the extremity. In the case of discoherent and dissociated recovery, ENMG, CT myelography and MRI of brachial plexus should be performed, and after determining the level of injury, a neurotization can be performed with orthopedic reconstructions in the later period (Blaauw et al. 2008).

The common treatment strategy for patients with brachial plexus injury is as follows:

Stage 1 (up to 6 months after injury), revision of brachial plexus with all appropriate neurotization procedures.

Stage 2 (3 months after the 1st surgery), free active muscle flaps transposition. Stage 3 (1 year after 2 nd operation), carpal joint fusion.

Stage 4 muscle transposition and shoulder joint fusion, if it is impossible to restore its movements (Thatte et al. 2013).

Shoulder joint complex is unique, it consists of five joints: the sterno-clavicular, acromio-clavicular, gleno-humeral joint, subacromial space, and thoraco-scapula junction (the last two are not true joints in the conventional sense of the word). Moreover it provides the greatest amount of movements of all joints in human body. Four major muscle groups of the shoulder girdle correspond for these movements: deltoid muscle, rotator cuff muscles (m. supraspinatus, $\mathrm{m}$. infraspinatus, $\mathrm{m}$. subscapularis, $\mathrm{m}$. teres minor), scapular group muscles (m. serratus anterior, m. trapezius, m. rhomboideus and $\mathrm{m}$. levator scapulae) and axio-humeral group (consisting of the $\mathrm{m}$. pectoralis mayor and m. latissimus dorsi). Deltoid muscle and muscles of rotator cuff are the main groups of muscles that provide movements in the gleno-humeral joint. Muscles of scapular group provide movements and active stabilization of the scapula. Muscles of axio-humeral group can act as muscles that adduct the upper extremity to the body, as internal rotators of the shoulder, as depressor muscles (for example during pull-up exercise), and as accessory respiratory muscles (Цимбалюк та спів.авт. 2001).

For innervation of muscles that provide movements in the shoulder joint there are responsible branches of brachial plexus that receive nerve fibers mostly from the upper roots C5 and C6. Deltoid muscle is 
innervated by axillary nerve which takes origin from the posterior cord, but receives fibers from C5 and C6 roots. Rotator cuff muscles, $\mathrm{m}$. supraspinatus and $\mathrm{m}$. infraspinatus are innervated by suprascapular nerve that comes from the upper trunk and receives fibers from $\mathrm{C} 5$ and $\mathrm{C} 6$ roots, $\mathrm{m}$. subscapularis is innervated by upper and lower subscapular nerves originating from the posterior cord and receive nerve fibers from $\mathrm{C} 5$ and $\mathrm{C} 6$ roots, and $\mathrm{m}$. teres minor is innervated by axillar nerve from the posterior cord and also receives nerve fibers from $\mathrm{C} 5$ and $\mathrm{C} 6$ roots. Scapular group, $\mathrm{m}$. serratus anterior is innervated by long thoracic nerve formed directly from C5, C6 and $\mathrm{C} 7$ roots, $\mathrm{m}$. rhomboideus major and $\mathrm{m}$. rhomboideus minor as well as $\mathrm{m}$. levator scapulae also, are innervated by dorsal scapular nerve directly from the C5 root. Axio-humeral group, m. pectoralis major is innervated by lateral pectoral nerve from the lateral cord with fibers from C5-C7 roots and medial pectoral nerve from the medial cord and takes nerve fibers from $\mathrm{C} 8$ and $\mathrm{T} 1$ roots, $\mathrm{m}$. latissimus dorsi is innervated by thoracodorsal nerve from the posterior cord and consists of nerve fasciculus from C6-C8 roots. From this distribution, we can see that for the function of the shoulder joint the most important components of the brachial plexus are the C5-C6 roots, the upper trunk, and the posterior cord (Chung et al. 2012).

Due to the fact that different types of brachial plexus injury are found in various forms of the shoulder joint complex dysfunction we developed classification of consequences of brachial plexus injury to the shoulder joint, on the base of which takes origin from the preservation of active movements and strength of scapular group of muscles.

Mild grade:

a. Abduction of the extremity from $60^{\circ}$ to $90^{\circ}$, flexion over $40^{\circ}$, full external rotation; b. Abduction of the extremity from $60^{\circ}$ to $90^{\circ}$, flexion over $40^{\circ}$, absent external rotation;

c. Moderate grade:

d. Abduction of the extremity from $30^{\circ}$ to $60^{\circ}$, flexion till $30^{\circ}$, external rotation till $30^{\circ}$;

e. Abduction of the extremity from $30^{\circ}$ to $60^{\circ}$, flexion till $30^{\circ}$, absent external rotation;

Severe grade:

Abduction of the extremity from $0^{\circ}$ to $30^{\circ}$, flexion and external rotation are absent, scapular movements moves along the arc preserved (m. Serratus anterior $>$ M3)

Very severe grade:

The extraction of shoulder flexion and external rotation, no saved only vertical movement of the blade ( $\mathrm{m}$. serratus anterior $<\mathrm{M} 3$ )

Abduction, flexion and external rotation are absent, only vertical scapular movements preserved (m. serratus anterio < M3)

Based on the above mentioned classification we developed the orthopedic treatment tactics of brachial plexus lesion which affected shoulder joint, depending on the severity of the injury. In cases of mild injury grade $\mathrm{A}$, it is appropriate to provide conservative treatment with the use of drug therapy and various methods of physiotherapy combined with mandatory pumping of functioning muscles, and development of movement in the joint. If patient has mild injury grade $B$, to improve external rotation, the L 'Episcopo operation should be performed. In case of moderate injury grade $\mathrm{A}$, if patient have functioning rotator cuff, improvement of abduction can be achieved by the Ober operation, or transposition of m. latissimus dorsi into position of the deltoid muscle. If patient have moderate injury grade B, L`Episcopo operation is performed which improves not 
only the external rotation but also slightly abduction. In case of severe grade lesion, with preservation of $\mathrm{m}$. supraspinatus function - transposition of $\mathrm{m}$. latissimus dorsi into position of deltoid muscle is appropriate, alternatively - shoulder joint fusion can be performed. In the case of Very severe grade injury - when there is no movement not only in the gleno-humeral joint but also only vertical movements of scapula can be performed - transposition of the trapezius muscle on the humerus by the method of Saha should be made (Цимбалюк та спів. авт. 2001).

Another way for the restoration of motion in the shoulder joint may be the approach depending on the level of brachial plexus lesion and preservation of function of groups of muscles of the shoulder girdle (Цимбалюк та спів.авт. 2001; Blaauw et al. 2008; Elhassan et al. 2010; South Glasgow University Hospitals Division 2010; Thatte et al. 2013; Sakellariou et al. 2014). So, what tasks will face the surgeon at different levels of the brachial plexus lesion?

1. In case of absence of deltoid muscle function and maintaining function of the rotator cuff and scapular groups:

a. Restoration of shoulder abduction;

b. Restoration of shoulder flexion.

2. In case of absence of deltoid muscle and rotator cuff function, but preserving function of the scapular group:

a. Restoration of shoulder abduction;

b. Restoration of shoulder external rotation;

c. Restoration of shoulder flexion.

3. In case of absence of deltoid muscle, rotator muscles and muscles of scapular group function:

a. Active stabilization of scapula;

b. Restoration of shoulder abduction;

c. Restoration of shoulder external rotation;

d. Restoration of shoulder flexion.

Impairment of the deltoid muscle function with preserved rotator cuff and scapular muscle group; it is possible in several variants of injury:

1. Isolated axillary nerve injury.

With this type of lesion in case of nerve integrity preserved - it is necessary to perform neurolysis and endoneurolysis of axillary nerve if possible. If the there is no possibility for neurolysis or patient has nerve rupture - suture or plastic of the injured axillary nerve with sural nerve autograft should be performed. In case of long-termed (over 6 months) injuries, but with maintaining ultrasonographic muscle structure, it is possible to perform neurotization of deltoid muscle. The most common method of neurotization of axillary nerve, it is Sansak's procedure, during this procedure the branch of radial nerve that innervates the long triceps head is used as a donor. Also as a donor for neurotization of axillary nerve 3-5 intercostal nerves, medial thoracic nerve, thoracodorsal and phrenic nerves can be used (Chung et al. 2012; Thatte et al. 2013; Sakellariou et al. 2014).

2. Injury of posterior and medial brachial plexus cords.

For this type of lesion, if the integrity of cords is preserved it is preferably to performe their neurolysis and endoneurolysis in early period after injury. If there is a damage to nerve cord integrity - nerve plastic is performed, and in cases of long-termed injuries but whith preservation of ultrasonographic muscle structure - neurotization of axillary nerve with intercostal or phrenic nerves is performed (Blaauw et al. 2008; Chung et al. 2012; Thatte et al. 2013; Sakellariou et al. 2014).

3. Retroclavicular compression of brachial plexus.

In this case, in the shortest time after injury neurolysis and decompression of brachial plexus should be performed with osteotomy of the clavicle in the middle third for better visualization of lesions. The neurotization of axillary nerve with intercostal or phrenic nerves can be made (Chung et al. 2012; Sakellariou et al. 2014). 
In patient with neglected injuries, when huge deltoid muscle hypotrophy and fibrotic changes in its structure are present the following reconstructive orthopedic surgeries are performed to compensate his lost functions:

1. Transposition of m.latissimus dorsi into position of the deltoid muscle.

Indications: cases of irreversible paralysis of deltoid muscle with preservation of function m.supraspinatus and m.serratus anterior (strength of M3 or higher). Transposition can be performed both as regional flap or free flap with following neurotization. However, after compartment of long-term results we revealed that free flap surgery gives significantly better functional results. This technique can be used as an alternative for shoulder joint fusion. 2. Ober operation

Indications: partially saved function of rotator cuff and the deltoid muscle, that allows abduction or flexion of the arm within 20-30 degrees.

Methodology: through the U-shaped approach (from the coracoid process toward the acromion, and then - to the outer edge of the scapula) the short head of the biceps and long head of the triceps muscles are exposed and released from the lateral edge of the scapula, transmitted them to the acromion and transosseous sutured to it with shoulder abduction angle of 45-60 degrees (Цимбалюк та спів.авт. 2001). 3. Fairbanks operation

Mobilization and release chuck muscle, greater pectoral muscle, and the anterior capsule of the shoulder joint (Chung et al. 2012).

4. L`Episcopo operation

Mobilization and release of subscapular muscle, m. pectoralis major, and of anterior part of the shoulder joint capsule, combined with transposition of the $\mathrm{m}$. teres major in the external rotator position (Цимбалюк та спів.авт. 2001; Chung et al. 2012).
5. Green-Tachdjian operation

Mobilization and elongation of $\mathrm{m}$. subscapularis and $\mathrm{m}$. pectoralis major, combined with transposition of the $\mathrm{m}$. teres major and $\mathrm{m}$. latissimus dorsi in the external rotator position.

6. Ingram operation

Elongation of the $\mathrm{m}$. subscapularis throughout all front surface of the scapula and transposition of the $\mathrm{m}$. teres major proximal to the site of insertions of $\mathrm{m}$. infraspinatus tendon.

7. Hoffer operation

Mobilization and release of subscapular muscle, $\mathrm{m}$. pectoralis major, and of anterior part of the shoulder joint capsule, combined with transposition of the $\mathrm{m}$. teres major and $\mathrm{m}$. latissimus dorsi into the rotator cuff (into the place of insertion of $\mathrm{m}$. supraspinatus).

8. Pearl operation

Mobilization and release of subscapular muscle, anterior shoulder joint capsulotomy under arthroscopic control, combined with transposition of the $\mathrm{m}$. teres major and $\mathrm{m}$. latissimus dorsi into the rotator cuff (into the place of insertion of $\mathrm{m}$. supraspinatus) (Chung et al. 2012).

Impairment of the deltoid muscle and muscles of rotator cuff function with preserved scapular muscle group - is possible in cases of lesion of the upper trunk of brachial plexus, proximal to suprascapular nerve branching.

If the patient has such type of lesion in case of upper trunk integrity is preserved, it is necessary to perform neurolysis and endoneurolysis as early as possible. If the there is a rupture of the trunk, its suture or plastic should be performed. In case of long-termed injuries with maintaining ultrasonographic muscle structure - it is possible to perform several types of neurotization (Blaauw et al. 2008; Chung et al. 2012; Thatte et al. 2013; Sakellariou et al. 2014): 1. Neurotization of the upper trunk by middle trunk; 
2. Neurotization of the $n$. suprascapularis with $n$. accessorius combined with Sansak's procedure;

3. Neurotization of the $n$. axillaris with $n$. phrenicus, medial pectoral nerve or intercostal nerves;

4. Neurotization of the $n$. suprascapularis with n. phrenicus, and as donor for neurotization of the $n$. axillaris we can use branch of the radial nerve to the long head of triceps, medial pectoral nerve or intercostal nerves (from the 3rd to the 5th).

In patient with neglected injuries of the upper trunk with hypotrophy and fibrotic changes in muscle structure - following reconstructive orthopedic surgeries can be performed:

1. Transposition of $\mathrm{m}$. latissimus dorsi into position of the deltoid muscle (Цимбалюк та спів.авт. 2001);

2. Transposition of the trapezius muscle on the humerus by Saha. Indications are cases of irreversible paralysis of the deltoid muscle and rotator cuff of the shoulder.

Methodology of Saha operation is as follows. Deltoid muscle is mobilized from acromion, trapezius muscle is mobilized from the scapula to the acromion level, then osteotomy of acromion $2 \mathrm{~cm}$ proximal from its lateral edge is performed. Trapezius muscle is mobilized proximal within $8-10 \mathrm{~cm}$ and then fixed by screw with part of acromion to the humerus (fixation is performed with upper limb abducted to $90^{\circ}$ and in maximum external rotation) (Цимбалюк та спів.авт. 2001; Elhassan et al. 2010).

Alternatively, the fusion of shoulder joint is performed (Цимбалюк та спів.авт. 2001; Blaauw et al. 2008; South Glasgow University Hospitals Division 2010).

Loss of function of the deltoid muscle, rotator cuff and scapular muscle group is possible in case of preganglionic brachial plexus injury. It is characterized not only by a gross violation of the shoulder joint function, but also by absence of active scapula movements including active stabilization, which leads to "winged scapula" symptom due to the long thoracic nerve lesion. It is typical for:

1. The root avulsion of C5-C6

For this type of lesion, early neurotization procedures are preferable. First of all, it is upper trunk neurotization with middle trunk or with contralateral C7 root. Also neurotization of separate nerves are possible. For example neurotization of $n$. suprascapularis with $\mathrm{n}$. accessorius or n. phrenicus; neurotization of $n$. axillaris with medial pectoral nerve, intercostal nerves or phrenic nerve (if it has not been used for neurotization of n. suprascapularis), Sansak's procedure (neurotization of the $\mathrm{n}$. axillaris with branch of the radial nerve to the long head of triceps). It is important to remember that the simultaneous use of intercostal nerves and phrenic nerve for neurotization - is not desirable, as it can lead to respiratory insufficiency, and the phenomenon of "breathing hand" (simultaneous movements of the upper extremity with breathing movements of the chest).

2. Total root avulsion (C5-T1) of brachial plexus.

It is the worst brachial plexus injury with a poor prognosis for restoration of the upper extremity function. In case of total avulsion, the first task is to restore the function of the hand, and active flexion of the elbow, that's why recovery of active movements in the shoulder joint is performed at the end of treatment. Quite often, when this type of lesion is observed, cervical plexus (roots C3-C4 after or, in some cases, before n. phrenicus branching) is used as donor nerves for neurotization of the upper trunk of Brachial plexus, or n. suprascapullaris, or n. thoracicus longus. Neurotization of $\mathrm{n}$. axillaris is performed residually (Chung et al. 2012; Thatte et al. 2013; Sakellariou et al. 2014).

The aim of orthopedic reconstruction in patients with avulsion brachial plexus lesions, and especially in case of total avulsion, is 
to stabilize the scapula actively (trapezius muscle transposition from contralateral shoulder into the place of $\mathrm{mm}$. rhomboidei; in case of m.pectoralis major preservation its transposition to the $\mathrm{m}$. serratus anterior is performed). For the restoration of movements in the shoulder joint transposition of the trapezius muscle on the front surface of the humerus by Saha can be used, or, in most cases - fusion of the shoulder joint (Цимбалюк та спів.авт. 2001; Elhassan et al. 2010).

Shoulder joint fusion (gleno-humeral arthrodesis) - after this surgical intervention "fusion" of scapula and humerus bones in functionally favorable position is achieved and patient receive movements of shoulder girdle which are made by scapular muscle group.

Indications for shoulder joint arthrodesis are the irreversible paralysis of rotator cuff and deltoid muscle while maintaining strength of $\mathrm{m}$. serratus anterior at the level of M3 and more.

Angle of shoulder abduction during arthrodesis is determined depending on the angle of the scapula abduction and power of $\mathrm{m}$. serratus anterior, muscle that innervates from the trunks of the brachial plexus only. Of course, strength of other muscles that control active scapula movements (m. trapezoideus, $\mathrm{mm}$. rhomboidei and $\mathrm{m}$. levator scapulae) are very important for good function of the upper extremity after arthrodesis (Цимбалюк та спів.авт. 2001).

\section{General considerations}

We used open and minimally invasive (when removing of the articular cartilage was performed using arthroscopic techniques, with subsequent fixation of the shoulder-blade joint through small access) methods of arthrodesis. We used three types of fixing devices: compression screws alone, compression screws conducted through unlocking plates, and locking reconstructive plates.

In our practice, we used needle EMG, to determine the dynamics of denervation- -reinervation processes that greatly reduce the making decision time on surgical intervention.

Long-term results of shoulder joint fusion were evaluated complexly (presence of bone fusion on $\mathrm{x}$-rays, range of shoulder girdle motions and subjective function evaluation scale SST (Simple Shoulder Test). Active abduction of shoulder-scapula segment to the angle $55-65^{\circ}$ was achieved in $31.3 \%$ of cases, $50 \%$ of patients got $40-50^{\circ}$ of abduction, and to the angle of $30-35^{\circ}$ arm abducted in $18.7 \%$ of patients. In two patients - fusion of the shoulder joint did not happen, which was associated with early prohibited ending of cast immobilization.

Long-term effects of shoulder joint fusion were evaluated on a Simple Shoulder Test scale through a telephone survey and the average SST score of shoulder function was $57.5 \%$.

\section{Conclusions}

1. Brachial plexus injury - severe lesion with poor prognosis and, in many cases, low function restoration after treatment. Despite the fact - that the problem is between the two specialties - neurosurgery and orthopedics - finally it is not solved by any of them.

2. Despite of the development of brachial plexus neurotization - orthopedic reconstructive surgeries occupy a stable niche in the treatment (including primary) of these patients and remain nearly the only method of choice in case of the inefficient muscles reinervation.

3. In case of isolated irreversible deltoid muscle denervation with preserved rotator cuff muscle function, we received the best restoration of shoulder elevation function after transposition of m. latisimus dorsi.

4. Shoulder joint arthrodesis is the treatment of choice for severe lesions and avulsions of brachial plexus. 
REFERENCES

Blaauw G., Muhlig R.S., Vredeveld J.W. (2008) 'Management of brachial plexus injuries' Adv Tech Stand Neurosurg., 33, pp. 201-231.

Chung K.C., Yang L., McGillicuddy J.E. (2012) 'Practical Management of Pediatric and Adult Brachial Plexus Palsies' Elsevier Saunders, 408 p.

Elhassan B., Bishop A., Shin A., Spinner, R. (2010) 'Shoulder tendon transfer options for adult patients with brachial plexus injury.' J Hand Surg Am., 35 (7), pp. 1211-1219. Jain D.K., Bhardwaj P., Venkataramani H., Sabapathy S.R. (2012) An epidemiological study of traumatic brachial plexus injury patients treated at an Indian centre' Indian J Plast Surg., 45 (3), pp. 498-503.

Midha R. (1997) 'Epidemiology of brachial plexus injuries in a multitrauma population' Neurosurgery, 40 (6), pp. 1182-1188.

Sakellariou V.I., Badilas N.K., Stavropoulos N.A., Mazis G., Kotoulas H.K., Kyriakopoulos S., Tagkalegkas I., Sofianos I.P. (2014) 'Treatment options for brachial plexus injuries' ISRN Orthop., 2014, 10 p. South Glasgow University Hospitals Division (2010) 'Scottish National Brachial Plexus Injury Service April 2009 to March 2010, Annual Report' 23 p.

Thatte M.R., Babhulkar S., Hiremath A. (2013) 'Brachial plexus injury in adults: Diagnosis and surgical treatment strategies' Ann Indian Acad Neurol., 16 (1), pp. 26-33. Цимбалюк В.І., Гайко Г.В., Сулій М.М., Страфун С.С. (2001) 'Хірургічне лікування ушкоджень плечового сплетення' Тернопіль “Укрмедкнига"., 212 с. 
Authors reported no source of funding. Authors declared no conflict of interest.

Author responsible for correspondence: Sergiy Strafun

State Institution "Institute of Traumatology and Orthopaedics of the Academy of Medical Sciences of Ukraine"

Bulvarno-Kudravska No27

01601, Kyiv

Ukraine

strafun@mail.ru
Autorzy nie zgłosili źródła finansowania.

Autorzy nie deklarowali konfliktu interesów.

Autor odpowiedzialny za korespondencje:

Sergiy Strafun

Institute of Traumatology and Orthopaedics of the Medical Sciences Academy of Ukraine

Bulvarno-Kudravska No27

01601, Kyiv

Ukraine

strafun@mail.ru 